\section{Somaclonal Variation in Habanero Pepper (Capsicum chinense Jacq.) as Assessed ISSR Molecular Markers}

\author{
Jericó J. Bello-Bello \\ Unidad de Bioquímica y Biología Molecular de Plantas, Centro de \\ Investigación Científica de Yucatán, Calle 43 \# 130, Chuburná de Hidalgo, \\ Mérida, Yucatán, CP 97200, México
}

\section{Lourdes G. Iglesias-Andreu \\ Instituto de Biotecnología y Ecología Aplicada, Universidad Veracruzana, Campus para la Cultura, las Artes y el Deporte, Av. de las Culturas Veracruzanas No. 101, Colonia Emiliano Zapata, Xalapa, Veracruz, CP 91090, México}

\begin{abstract}
Susana A. Avilés-Viñas, Eunice Gómez-Uc, Adriana Canto-Flick, and Nancy Santana-Buzzy ${ }^{1}$

Unidad de Bioquímica y Biología Molecular de Plantas, Centro de Investigación Científica de Yucatán, Calle 43 \# 130, Chuburná de Hidalgo, Mérida, Yucatán, CP 97200, México

Additional index words. genetic variability, organogenesis, plant regeneration, somatic embryogenesis

Abstract. Intersimple sequence repeat (ISSR) markers were used to evaluate the effects of in vitro culture on genetic variation in Habanero pepper (Capsicum chinense Jacq.) regeneration protocols. A total of 219 ISSR clear and reproducible fragments were generated with 13 ISSR primers in direct organogenesis, direct and indirect somatic embryos, and the embryogenic callus system. A cluster analysis was performed to express in the form of dendrogram the relationships among different regeneration systems and the genetic variability detected. Genetic distance analysis indicated that our regeneration protocols are inappropriate for micropropagation, conservation, or genetic transformation; however, they may be applicable to breeding. This is the first report on the use of molecular analysis to evaluate genetic variation of in vitro-regenerated plants of Habanero pepper using ISSR markers.
\end{abstract}

In vitro cell and tissue-based systems have tremendous potential in fundamental research and for commercial applications such as clonal propagation, genetic engineering, and production of valuable metabolites. Plant cell and tissue culture has been described as one of the most significant potential tools for the improvement of plants as the result of the ability to apply the selection cell to recover useful genetic variants. The cultivation of plant cells has provided an option to obtain greater genetic variability relatively quickly without sophisticated technology (Larkin and Scowcroft, 1981; Shu and Lagoda, 2007). The term "somaclonal variation" describes the tissue culture-induced stable genetic, epigenetic, or phenotypic variation in clonally propagated plant populations (Larkin and Scowcroft, 1981).

Somaclonal variation is considered to be one of the main bottlenecks in the development of micropropagation procedures,

Received for publication 20 Aug. 2013. Accepted for publication 23 Jan. 2014.

${ }^{1}$ To whom reprint requests should be addressed; e-mail buzzy@cicy.mx. especially in view of large-scale commercial operations for which the strict maintenance of genetic and agronomic traits from selected individuals is required. However, this variation generated in vitro has been efficiently exploited for the development of new varieties with superior agronomic traits in diverse species (Jain, 2001).

Some changes induced by in vitro culture cannot be observed because the structural difference in the gene product does not always alter its biological activity to such an extent that can be observed in the phenotype. Different molecular techniques are currently available to detect sequence variation between closely related genomes such as those between source plants and somaclones. These include random amplified polymorphic DNA (RAPD), ISSR, microsatellites or simple sequence repeat (SSR), restriction fragment length polymorphism, and amplified fragment length polymorphism. The use of these molecular markers to detect variations at genomic DNA level in plant has been clearly documented (Andreev et al., 2005; Gernand et al., 2007; Jin et al., 2008; Li et al., 2007; Sreedhar et al., 2007).

Somaclonal variation has been reported in numerous crop species such as grapevine
(Schellenbaum et al., 2008), potato (Aversano et al., 2009), and maize (Osipova et al., 2011). Nevertheless, critical analysis of somaclonal variants in Capsicum spp. is scarce (Anu et al., 2004; Hossain et al., 2003). Recently, SolísMarroquín et al. (2011) reported a salinity tolerance embryogenic line of Habanero pepper. The aim of this work was assessing genetic variation generated from different in vitro regeneration systems in Habanero pepper (C. chinense Jacq.) using ISSR molecular markers.

\section{Materials and Methods}

Preparation of explants. Seeds of the var. Mayan Báalché (Registration No. $2367-$ chl-021-080110/c) (orange fruit) of Habanero pepper (Capsicum chinense Jacq.) were obtained from the Scientific Research Center of Yucatan germplasm bank. Seeds were first submerged in ethanol at $70 \%(\mathrm{v} / \mathrm{v})$ for $5 \mathrm{~min}$ and subsequently in a solution of commercial chlorine (Cloralex ${ }^{\circledR}, \mathrm{NL}$, MX; $6 \%$ active chlorine) diluted to $30 \%$ (v/v), for $15 \mathrm{~min}$. The seeds were then rinsed three times with sterile distilled water and placed in baby food jars containing $20 \mathrm{~mL}$ of Murashige and Skoog (MS) medium (Murashige and Skoog, 1962) semisolid medium supplemented with $1.15 \mu \mathrm{M}$ gibberellic acid, 3\% (w/v) sucrose; $\mathrm{pH}$ was adjusted to 5.8 before adding $0.22 \%(\mathrm{w} / \mathrm{v})$ Gelrite $^{\circledR}$ (Sigma Chemical Company, St. Louis, MO) and autoclaving. Seeds were incubated in darkness at $25 \pm 2{ }^{\circ} \mathrm{C}$. On germination $(15 \mathrm{~d})$, apical shoots $(\approx 2 \mathrm{~cm}$ long) were cut off under sterile conditions and transferred to the fresh MS medium without growth regulators.

Direct organogenesis induction. When the seedlings from the apical shoots on the sprouted seeds, had reached 6 to $8 \mathrm{~cm}$ (45 to $60 \mathrm{~d}$ old), nodes 1 to $1.5 \mathrm{~cm}$ in length were used as explants for organogenesis induction. Thirty nodes were used per treatment distributed in 10 Magenta boxes (Sigma Chemical Company) containing $40 \mathrm{~mL}$ of MS semisolid medium supplemented with $3.4 \mu \mathrm{M}$ thidiazuron (TDZ), $3.4 \mu \mathrm{M}$ paclobutrazol, and $3 \%(\mathrm{w} / \mathrm{v})$ sucrose. The $\mathrm{pH}$ was adjusted to 5.8 before adding $0.22 \%(\mathrm{w} / \mathrm{v})$ Gelrite $^{\circledR}$. The explants were labeled and incubated at $25 \pm 2{ }^{\circ} \mathrm{C}$ under cool white fluorescent light (40 to $50 \mu \mathrm{mol} \cdot \mathrm{m}^{-2} \cdot \mathrm{s}^{-1}$ ) with a $16 / 8$-h photoperiod, according to Bello-Bello et al. (2010).

Direct somatic embryogenesis induction. For induction of direct somatic embryogenesis, segments hypocotyl from germinated seeds $(15 \mathrm{~d}$ old) were used. Thirty explants were used per treatment, distributed in $10 \mathrm{Ma}-$ genta boxes containing $40 \mathrm{~mL}$ of MS semisolid medium supplemented with $9.05 \mu \mathrm{M}$ 2,4-dichlorophenoxyacetic acid (2,4-D) and $3 \%(\mathrm{w} / \mathrm{v})$ sucrose. The $\mathrm{pH}$ was adjusted to 5.8 before adding $0.22 \%(\mathrm{w} / \mathrm{v})$ Gelrite $^{\circledR}$. The explants were labeled and incubated at $25 \pm$ $2{ }^{\circ} \mathrm{C}$ under continuous cool white fluorescent light (40 to $50 \mu \mathrm{mol} \cdot \mathrm{m}^{-2} \cdot \mathrm{s}^{-1}$ ) for $1 \mathrm{month}$ following the protocol of López-Puc et al. (2006). 
Indirect somatic embryogenesis induction. For induction of indirect somatic embryogenesis, segments hypocotyl from germinated seeds ( $15 \mathrm{~d}$ old) were used. Thirty explants were used per treatment, distributed in 10 Magenta boxes (Sigma Chemical Company) containing $40 \mathrm{~mL}$ of MS semisolid medium supplemented with $9.05 \mu \mathrm{M}$ 2,4-D and $3 \%(\mathrm{w} / \mathrm{v})$ sucrose. Two months after culture, the callus formed around the hypocotyl was transferred into $250-\mathrm{mL}$ erlenmeyer flasks ( $1 \mathrm{~g}$ of callus) containing $50 \mathrm{~mL}$ of MS liquid medium supplemented with $4.52 \mu \mathrm{M}$ $2,4-\mathrm{D}$ and $3 \%(\mathrm{w} / \mathrm{v})$ sucrose. The $\mathrm{pH}$ was adjusted to 5.8. The cellular suspensions were placed under continuous light at 40 to $50 \mu \mathrm{mol} \cdot \mathrm{m}^{-2} \cdot \mathrm{s}^{-1}$ and $25 \pm 2{ }^{\circ} \mathrm{C}$. Cell suspensions were maintained in agitation at $100 \mathrm{rpm}$. After 2 months, somatic embryos were induced in MS liquid medium containing $3.4 \mu \mathrm{M}$ TDZ according to Zapata-Castillo et al. (2007). The $\mathrm{pH}$ was adjusted to 5.8. The cellular suspensions were placed under continuous light at 40 to $50 \mu \mathrm{mol} \cdot \mathrm{m}^{-2} \cdot \mathrm{s}^{-1}$ and $25 \pm 2{ }^{\circ} \mathrm{C}$. It was inoculated with $1 \mathrm{~g}$ of the embryogenic biomass obtained by each $250-\mathrm{mL}$ erlenmeyer flask containing $50 \mathrm{~mL}$ of medium.

DNA isolation. Samples from shoots, callus, and somatic embryos obtained directly or indirectly, which were used for DNA extraction, were obtained from culture systems described previously. For DNA extraction, we used the protocol reported by Dellaporta et al. (1983). DNA concentration was determined using a spectrometer (Genesys 10uv, IL). As a control, the DNA of seedlings ( 30 to $45 \mathrm{~d}$ old) obtained from seeds was germinated in inert substrate (peatmoss) and maintained under greenhouse conditions. Irrigations were carried out on alternate days to avoid excessive moisture during the seedling stage.

ISSR-PCR analysis. Thirteen primers were tested to screen the DNA polymorphism in shoots, callus, and embryos (Table 1). ISSR amplification was performed according to Zietkiewicz et al. (1994) in a total volume of $30 \mu \mathrm{L}$ containing $50 \mathrm{ng}$ DNA template, $3 \mu \mathrm{L}$ of $10 \times$ polymerase chain reaction buffer, $2 \mathrm{mM} \mathrm{MgCl}_{2}, 200 \mu \mathrm{M}$ of each dNTP, $10 \mu \mathrm{M}$ primer, and $2 \mathrm{U}$ Taq DNA polymerase (Invitrogen, CA). DNA amplification was performed using the following cycling program: one cycle at $94^{\circ} \mathrm{C}$ for $4 \mathrm{~min} ; 37$ cycles at $94{ }^{\circ} \mathrm{C}$ for $40 \mathrm{~s}, 35,37,40$, or $45^{\circ} \mathrm{C}$ (according to the primer) for $40 \mathrm{~s}$ and $72{ }^{\circ} \mathrm{C}$ for $50 \mathrm{~s}$; and a final extension at $72{ }^{\circ} \mathrm{C}$ for $7 \mathrm{~min}$. Amplification was performed in a Thermocycler (My cycler; Bio-Rad). ISSR fragments were separated by electrophoresis on $6 \%$ polyacrylamide gels in $1 \times$ TAE buffer (Tris-Acetate-EDTA) and the band profiles were detected by silver nitrate staining. To increase the confidence level of the fragments included in the matrices, the primers that generated multiple discrete bands that were observed in the three replicates were selected.

Data analysis. ISSR reproducible fragments were scored as present (1) or absent (0), and bands were entered in a computer file as a binary matrix. The matrices were then analyzed using MVSP 3.0 (multivariate statistical package). Similarity for qualitative data was computed using Jaccard's coefficient method. The similarity matrixes were subjected to cluster analysis by unweighted pair group method with arithmetic averages; the resulting cluster was expressed as a dendrogram constructed from matrices that included monomorphic and polymorphic bands.

\section{Results and Discussion}

Figure 1 shows shoots formation from nodes (Fig. 1A), direct somatic embryogenesis

Table 1. ISSR primer used for detecting somaclonal variation in Habanero pepper (C. chinense).

\begin{tabular}{llcccc}
\hline Primer & \multicolumn{1}{c}{ Sequence $\left(5^{\prime}-3^{\prime}\right)$} & Tm $\left({ }^{\circ} \mathrm{C}\right)$ & No. of bands & Range $(\mathrm{pb})$ & $\% \mathrm{P}$ \\
\hline IS-01 & GTAGTAGATAGATA & 40 & 22 & $180-2500$ & 9 \\
IS-02 & GTAGTAGATAGATARG & 45 & 14 & $140-3000$ & 28 \\
IS-03 & GTA GTAGATAGATARY & 45 & 17 & $200-2900$ & 35.29 \\
IS-11 & GATAGATAGATA & 35 & 27 & $160-2900$ & 40.74 \\
IS-12 & GTAGTAGATAGATARG & 37 & 16 & $120-2600$ & 31.25 \\
IS-13 & YRGATAGATAGATA & 37 & 19 & $160-2500$ & 55.55 \\
IS-14 & GACAGACAGACAGACA & 40 & 18 & $280-2800$ & 16.66 \\
IS-15 & GACAGACAGACARG & 45 & 12 & $150-2200$ & 33.33 \\
IS-16 & YRGACAGACAGACA & 40 & 5 & $220-800$ & 0 \\
IS-17 & GACACGACAC & 35 & 25 & $120-1900$ & 12 \\
IS-18 & ACTGACTGACTG & 40 & 18 & $180-2000$ & 27.77 \\
IS-19 & ACTGACTGACTG & 45 & 11 & $250-2900$ & 9 \\
IS-20 & YRACTGCTGACTG & 40 & 15 & $220-2700$ & 60 \\
\hline
\end{tabular}

ISSR = intersimple sequence repeat; $\mathrm{Tm}=$ annealing temperature; $\% \mathrm{P}=$ percentage of polymorphism; $\mathrm{R}=$ $\mathrm{A}$ and $\mathrm{G}$ residues; $\mathrm{Y}=\mathrm{C}$ and $\mathrm{T}$ residues.
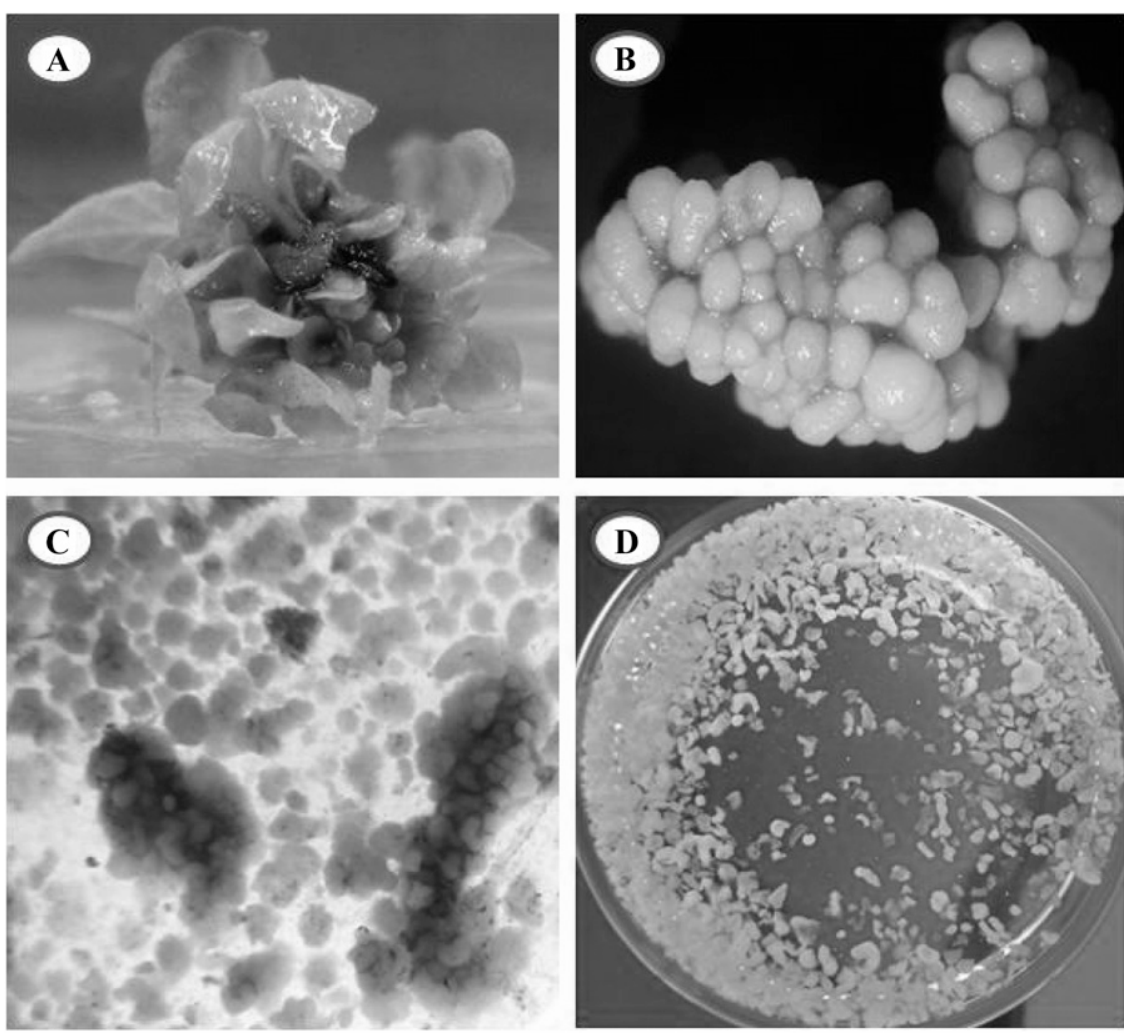

Fig. 1. The image shows the source of plant material used for DNA profile analysis of different regeneration systems in Habanero pepper (C. chinense Jacq.): (A) direct organogenesis; (B) direct somatic embryogenesis; (C) indirect somatic embryogenesis; and (D) somatic embryos obtained from embryogenic callus. 
primer IS-20 [percentage of polymorphism $(\% \mathrm{P})=60]$ and the lowest by primers IS-01 $(\% \mathrm{P}=9)$, IS-19 $(\% \mathrm{P}=9)$, and IS-18 $(\% \mathrm{P}=$ 12). ISSR analysis revealed a total of 197 amplified fragments from the control plant DNA. A summary of the effectiveness of the ISSR markers appears in Table 2. According to results of the cluster analyses based on the ISSR fragments (Fig. 2), the regeneration systems were distributed as follows: Group I included only the control plant; Group II included organogenesis system, which contrary to the expected, showed the greatest genetic similarity $(0.87)$ with the control plant. Group III comprised direct somatic embryogenesis and indirect somatic embryogenesis systems, and Group IV included only embryogenic callus system, which represented the lowest genetic similarity $(0.72)$ with the control plant (Fig. 2). Direct and indirect embryogenesis was similar in terms of the variation level (0.83), sharing 188 bands in common and having 21 bands absent; however, they differed in 10 polymorphic bands. Figures $3 \mathrm{~A}$ and $3 \mathrm{~B}$ show polymorphic primers (IS-11 and IS-18, respectively) evaluated in the different regeneration systems using ISSR. Analyses of callus and indirect somatic embryogenesis revealed 169 bands in common and 21 bands

Table 2. Effectiveness of ISSR markers for detecting polymorphism in Habanero pepper somaclonal variation.

\begin{tabular}{lc}
\hline & ISSR \\
\hline Number of primers screened & 20 \\
Number of primers used & 13 \\
Total bands scored & 219 \\
Polymorphic fragments scored & 64 \\
Average bands per primer & 16.8 \\
Range (pd) & $120-3000$ \\
Percentage of polymorphism & 27.5 \\
\hline
\end{tabular}

ISSR $=$ intersimple sequence repeat. absent. A total of 29 polymorphic bands were detected in both processes, from which we can infer that part of the variation found in indirect somatic embryogenesis may have originated in the callus phase. In our study, detected variation was higher in callus than the other tissue systems analyzed, probably as a result of tissues in the callus phase remaining exposed longer to 2,4-D (4-month-old cultures). Jain (2001) proposed that in prolonged periods of culture exposed to 2,4-D exist, there was accumulation of mutations. According to Phillips et al. (1994), the auxin 2,4-D is commonly used to induce callus and/or somatic embryogenesis. However, the 2,4-D has been shown to cause genetic and/or epigenetic DNA changes. According to Kaeppler et al. (2000), DNA methylation levels increased with increasing amounts of the auxin 2,4-D. It may be an important factor affecting tissue culture-induced variation.

Although plants regenerated from in vitro regeneration systems are expected to be homogenous, now it is known that as a result of intrinsic and extrinsic factors affecting development under artificial conditions, there is a high probability of epigenomic and genomic changes (Neelakandan and Wang, 2012). Numerous reports have referred to the presence of somaclonal variants in regenerated plants by different in vitro culture systems using molecular markers. Alhani and Wilkinson (1998), working with ISSR, detected somaclonal variation in induced callus of potato, and Leroy et al. (2000) obtained similar results in cauliflower callus. Thomas et al. (2006), using direct somatic embryogenesis, reported up to $55 \%$ somaclonal variation in the regenerated tea plant (Camellia sinensis). In contrast, Lu et al. (2011), using eight selected primers, found no evidence of variation during direct organogenesis in banana cultivars (Musa spp.). The use of different molecular markers for

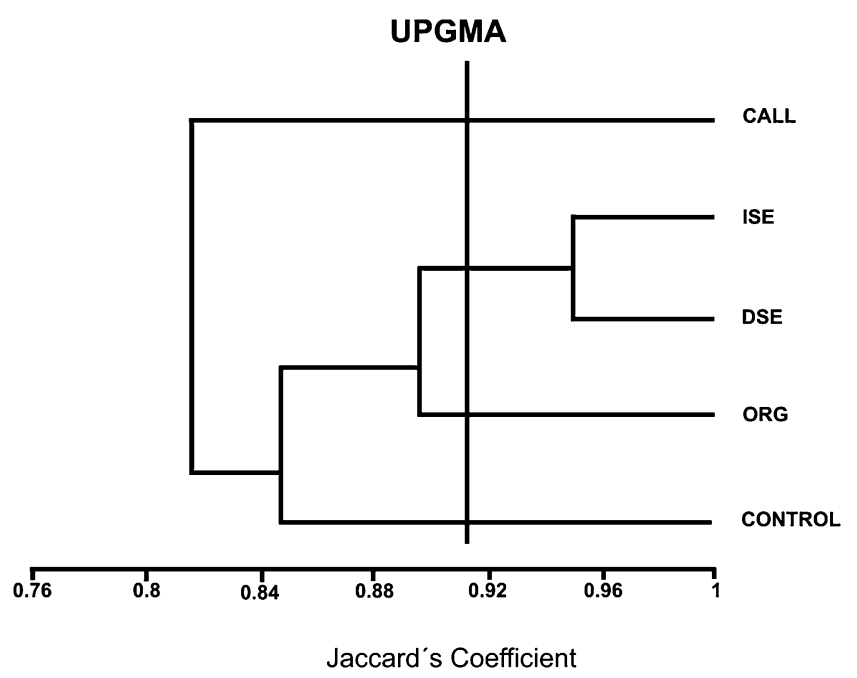

Fig. 2. Genetic similarity dendrogram (Jaccard's coefficient) by the UPGMA cluster analysis based on ISSR band patterns showing the relationship among different in vitro regeneration systems of Habanero pepper: direct organogenesis (ORG), direct somatic embryogenesis (DSE), indirect somatic embryogenesis (ISE), embryogenic callus (CALL), and donor plants (CONTROL). UPGMA = unweighted pair group method with arithmetic; ISSR = intersimple sequence repeat. evaluating the variation induced during in vitro culture has been reported. RusKortekaas et al. (1994), working with RAPD and SSR, observed genetic variation in $\mathrm{Lyco}-$ persicon esculentum regenerated plants while studying the descendants obtained from callus. More precisely, RAPD and ISSR markers have been used in Camellia ssp. (Devarumath et al., 2002), Prunus dulcis Mill (Martins et al., 2004), and banana (Lakshmanan et al., 2007). Martins et al. (2004), using RAPD and ISSR markers to evaluate Prunus dulcis plants obtained from axillary bud proliferation, did not detect polymorphic bands, corroborating the genetic fidelity of this system for clonal micropropagation. Similar results have been reported by Lakshmanan et al. (2007), who also detected a high genetic homogeneity in banana plants obtained through in vitro culture of axillary buds. In Capsicum annuum, Hossain et al. (2003), using RAPD, reported somaclonal variants in plants regenerated through direct organogenesis. Variation was also found in some morphological characters such as growth habit, stem color, antocianine content, and flower and fruit color. Similar results were reported by Anu et al. (2004) working with the same species (C. annuum) who observed variation in plant growth habit, flower position, fruit shape, and fruit color. Thul et al. (2012) to analyze the molecular profiling for genetic variability in Capsicum species based on ISSR and RAPD markers observed that ISSR primers were more efficient to reveal DNA polymorphism among genotypes.

Although the mechanism of somaclonal variation is still not completely understood, several explanations have been proposed. In plant tissue culture, changes in DNA methylation and in histone modifications have also been reported in many cases during the dedifferentiation pathway, ranging from axillary shoot proliferation to protoplast formation (Ruffoni and Savona, 2013). In vitro culture is believed to destabilize the genetic and epigenetic program of intact plant tissue and can lead to chromosomal and DNA sequence variations, methylation changes, transposon activation, and generation of somaclonal variants (Neelakandan and Wang, 2012). Changes in the epigenome have been proposed to be an important source of somaclonal variation (i.e., phenotypic variation among regenerated plants) for decades (Kaeppler et al., 2000; Kaeppler and Phillips, 1993a, 1993b; Miguel and Marum, 2011; Neelakandan and Wang, 2012; Rhee et al., 2010; Stroud et al., 2013; Thorpe, 2006). Indeed, some evidence suggesting changes in the epigenome of regenerated plants have been reported at several specific loci or by methods such as methylation-sensitive restrictive enzyme digestion (Neelakandan and Wang, 2012). Changes in methylation may explain a component of somaclonal variation, a phenomenon in which plants derived from tissue culture manifest phenotypic variability. These changes generate an unexpectedly rich source of genetic diversity in plants and have been used to introduce novel traits into a wide 


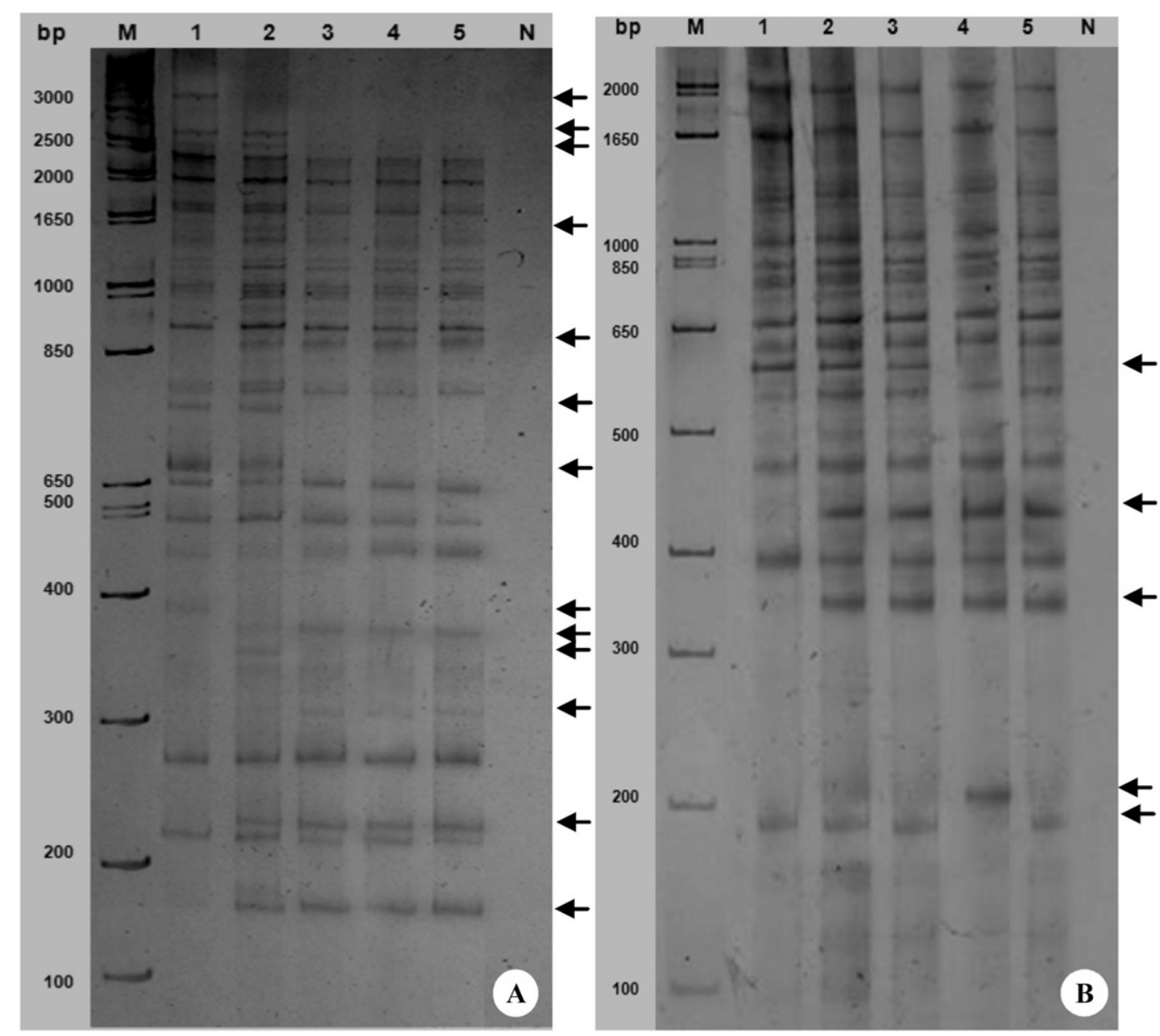

Fig. 3. Electrophoresis pattern of ISSR markers obtained from different regeneration systems of Habanero pepper. ISSR profiles using primes IS-11 (A) and IS-18 (B), respectively, in mother plant (Lane 1), direct organogenesis (Lane 2), direct somatic embryogenesis (Lane 3), indirect somatic embryogenesis (Lane 4), and callus $($ Lane 5 ). $\mathrm{ISSR}=$ intersimple sequence repeat; $\mathrm{N}=$ negative control; $\mathrm{M}=$ molecular mass marker $1 \mathrm{~kb}$ plus DNA ladder.

range of crops. In many cases, it has been shown to be a potential tool for plant breeding when used to engineer crop cultivars with agronomical useful characteristics. This study allows to identify new sources of genetic variation for Capsicum chinense, which are promising for obtaining tolerant lines to different types of stress (biotic and abiotic), taking into account that in vitro selection methods significantly reduce the time for improvement of some plant species of economic interest. In conclusion, in vitro plants regeneration of Habanero pepper could be a promising system for breeding program we have been developing for some years now.

\section{Literature Cited}

Alhani, M.C. and M.J. Wilkinson. 1998. Inter simple sequence repeat polymerase chain reaction for the detection of somaclonal variation. Plant Breed. 117:573-575.

Andreev, O., K.V. Spiridonova, V.T. Solovyan, and V.A. Kunakh. 2005. Variability of ribosomal RNA genes in Rauwolfia species: Parallelism between tissue culture-induced rearrangements and interspecies polymorphism. Cell Biol. Intl. 29:21-27.

Anu, A., K. Babu, and K. Peter. 2004. Variations among somaclones and its seedling progeny in Capsicum annuum. Plant Cell Tissue Organ Cult. 76:261-267.
Aversano, R., S. Savarese, J. Maria De Nova, L. Frusciante, M. Punzo, and D. Carputo. 2009. Genetic stability at nuclear and plastid DNA level in regenerated plants of Solanum species and hybrids. Euphytica 165:353-361.

Bello-Bello, J.J., A. Canto-Flick, E. Balam-Uc, E. Gómez-Uc, M.L. Robert, L.G. IglesiasAndreu, and N. Santana-Buzzy. 2010. Improvement of in vitro proliferation and elongation of Habanero pepper shoots (Capsicum chinense Jacq.) by temporary immersion. HortScience 45:1-6.

Dellaporta, S.L., J. Wood, and J.B. Hicks. 1983. A plant DNA minipreparation: Version II. Plant Mol. Biol. Rpt. 1:19-22.

Devarumath, R., S. Nandy, V. Rani, S. Marimuthu, N. Muraleedharan, and S. Raina. 2002. RAPD, ISSR and RFLP fingerprints as useful markers to evaluate genetic integrity of micropropagated plants of three diploid and triploid elite tea clones representing Camellia sinensis (China type) and C. assamica ssp. assamica (AssamIndia type). Plant Cell Rpt. 21:166-173.

Gernand, D., H. Golczyk, T. Rutten, T. Ilnicki, A. Houben, and A.J. Joachimiak. 2007. Tissue culture triggers chromosome alterations, amplification, and transposition of repeat sequences in Allium fistulosum. Genome 50: 435-442.

Hossain, A., K. Konisho, M. Minami, and K. Nemoto. 2003. Somaclonal variation of regenerated plants in chili pepper (Capsicum annuum L.). Euphytica 130:233-239.
Jain, S.M. 2001. Tissue culture-derived variation in crop improvement. Euphytica 118:153-166.

Jin, S., R. Mushke, H. Zhu, L. Tu, Z. Lin, Y. Zhang, and X. Zhang. 2008. Detection of somaclonal variation of cotton (Gossypium hirsutum) using cytogenetics, flow cytometry and molecular markers. Plant Cell Rpt. 27:1303-1316.

Kaeppler, S.H., H.F. Kaeppler, and Y. Rhee. 2000. Epigenetic aspects of somaclonal variation in plants. Plant Mol. Biol. 43:179-188.

Kaeppler, S.M. and R.L. Phillips. 1993a. DNA methylation and tissue culture-induced variation in plants. In Vitro Cell. Dev. Biol. 29:125130.

Kaeppler, S.M. and R.L. Phillips. 1993b. Tissue culture-induced DNA methylation variation in maize. Proc. Natl. Acad. Sci. USA 90:87738776.

Lakshmanan, V., S.R. Venkataramareddy, and B. Neelwarne. 2007. Molecular analysis of genetic stability in long-term micropropagated shoots of banana using RAPD and ISSR markers. Plant Biotechnol. 10(1).

Larkin, P.J. and W.R. Scowcroft. 1981. Somaclonal variation: A novel source of variability from cell cultures for plant improvement. Theor. Appl. Genet. 60:197-214.

Leroy, X.J., K. Leon, and G. Charles. 2000 Cauliflower somatic embryogenesis and analysis of regenerant stability by ISSRs. Plant Cell Rpt. 19:1102-1107.

Li, X., X. Yu, N. Wang, Q. Feng, Z. Dong, L. Liu, J. Shen, and B. Liu. 2007. Genetic and epigenetic 
instabilities induced by tissue culture in wild barley [Hordeum brevisubulatum (Trin.)]. Plant Cell Tissue Organ Cult. 90:153-168.

López-Puc, G., A. Canto-Flick, F. Barredo-Pool, P. Zapata-Castillo, M. Montalvo-Peniche, F. Barahona-Pérez, and N. Santana-Buzzy. 2006. Direct somatic embryogenesis: A highly efficient protocol for in vitro regeneration of Habanero pepper (Capsicum chinense Jacq.). HortScience 41:1-7.

Lu, Y., X. Zhang, J. Pu, Y. Qi, and Y. Xie. 2011. Molecular assessment of genetic identity and genetic stability in banana cultivars (Musa spp.) from China using ISSR markers. AJCS 5:25-31.

Martins, M., D. Sarmento, and M.M. Oliveira. 2004. Genetic stability of micropropagated almond plantlets as assessed by RAPD and ISSR markers. Plant Cell Rpt. 23:492-496.

Miguel, C. and L. Marum. 2011. An epigenetic view of plant cells cultured in vitro: Somaclonal variation and beyond. J. Expt. Bot. doi: 10.1093/jxb/err 155 .

Murashige, T. and F.A. Skoog. 1962. A revised medium for rapid growth and bioassays with tobacco cultures. Physiol. Plant. 15:473-497.

Neelakandan, A.K. and K. Wang. 2012. Recent progress in the understanding of tissue culture induced genome level changes in plants and potential applications. Plant Cell Rpt. 31:597620 .

Osipova, E.S., E.A. Lysenko, A.V. Troitsky, Y.I. Dolgikh, Z.B. Shamina, and S.A. Gostimskii. 2011. Analysis of SCAR marker nucleotide sequences in maize (Zea mays L.) somaclones. Plant Sci. 180:313-322.

Phillips, R.L., S.M. Kaeppler, and P. Olhoft. 1994. Genetic instability of plant tissue cultures: Breakdown of normal controls. Proc. Natl. Acad. Sci. USA 91:5222-5226.

Rhee, Y., R.S. Sekhon, S. Chopra, and S. Kaeppler. 2010. Tissue culture induced novel epialleles of a Myb transcription factor encoded by pericarp color1 in maize. Genetics 186:843-855.

Ruffoni, B. and M. Savona. 2013. Physiological and biochemical analysis of growth abnormalities associated with plant tissue culture. Hort. Environ. Biotechnol. 54:191-205.

Rus-Kortekaas, W., M.J.M. Smulders, P. Arens, and B. Wosman. 1994. Direct comparison of levels of genetic variation in tomato detected by GACA-containing microsatellite probe and random amplified polymorphic DNA. Genome 37:375-381.

Schellenbaum, P., V. Mohler, G. Wenzel, and B. Walter. 2008. Variation in DNA methylation patterns of grapevine somaclones (Vitis vinifera L.). BMC Plant Biol. 8:78.

Shu, Q. and P. Lagoda. 2007. Mutation techniques for gene discovery and crop improvement. Mol. Plant Breed. 5:193-195.

Solís-Marroquín, D., C.A. Lecona-Guzmán, A. Canto-Flick, J.J. Bello-Bello, L. IglesiasAndreu, and N. Santana-Buzzy. 2011. In vitro selection of a salt-tolerant embryogenic line in Habanero pepper (Capsicum chinense Jacq.). HortScience 46:1666-1671.
Sreedhar, R.V., L. Venkatachalam, and N. Bhagyalakshmi. 2007. Genetic fidelity of longterm micropropagated shoot cultures of vanilla (Vanilla planifolia Andrews) as assessed by molecular markers. Biotechnol. J. 2:10071013.

Stroud, H., B. Ding, S.A. Simon, S. Feng, M. Bellizzi, M. Pellegrini, G.L. Wang, B.C. Meyers, and S.E. Jacobsen. 2013. Plants regenerated from tissue culture contain stable epigenome changes in rice. eLIFE, $<\mathrm{http}$ ://dx.doi. org/10.7554/eLife.00354>.

Thomas, J., D. Vijayan, S.D. Joshi, S.J. Lopez, and R.R. Kumar. 2006. Genetic integrity of somaclonal variants in tea [Camellia sinensis (L.) O Kuntze] as revealed by inter simple sequence repeats. J. Biotechnol. 123:149-154.

Thorpe, T.A. 2006. History of plant tissue culture. Methods Mol. Biol. 318:9-32.

Thul, S.T., M.P. Darokar, A.K. Shasany, and S.P.S. Khanuja. 2012. Molecular profiling for genetic variability in Capsicum species based on ISSR and RAPD markers. Mol. Biotechnol. 51:137147.

Zapata-Castillo, Y.P., A. Canto-Flick, G. LópezPuc, A. Solís-Ruiz, F. Barahona-Pérez, and N. Santana-Buzzy. 2007. Somatic embryogenesis in Habanero pepper ( $C$. chinense Jacq.) from cell suspensions. HortScience 42:1-5.

Zietkiewicz, E., A. Rafalski, and D. Labuda. 1994. Genome fingerprinting by simple sequence repeat (SSR)-anchored polymerase chain reaction amplification. Genomics 20:176-183. 